\title{
Frederick Douglass's “Our National Capital”: Updating L'Enfant for an Era of Integration
}

\author{
GRAHAM CULBERTSON
}

In this article I argue that scholars have been insufficiently attentive to Frederick Douglass's engagement with American cities, particularly Washington, DC. I show that Frederick Douglass's i 877 speech "Our National Capital" should not be relegated, as it usually is, to an autobiographical footnote, but is in fact an important document both in Douglass's philosophy and in the history of Washington, DC. This essay places that speech in both of those traditions. First, I give a brief account of Pierre L'Enfant's late eighteenth-century plans for Washington, DC as a cosmopolitan and regionally inclusive place, then use several figures, including Charles Dickens and Eastman Johnson, to show that actually existing DC failed to meet those ideals. The bulk of the essay then shows that Douglass's speech has great affinities with L'Enfant's original ideas, with Douglass adding the crucially important category of race to L'Enfant's vision for the city. I also use a number of Douglass's other writings, including speeches, essays, and autobiographies, to show that "Our National Capital" can serve as a capstone for Douglass's career, in which he articulates how an urban environment should function if it is to live up to his ideals.

\section{INTRODUCTION}

In making their case for Frederick Douglass as a philosopher, Bill E. Lawson and Frank M. Kirkland argue that a central philosophical issue lay at the heart of all of Douglass's activism: "Douglass inserts a genuinely philosophical problem like a detonator into this many-leveled enterprise, viz., the dualistic and duellistic American experiment of constitutional democracy and slavery or tyranny." "In their persuasive reading, Douglass is the great theorist of the central American contradiction, the dual and dueling doctrines of liberty and slavery. At the heart of Douglass's career is a series of questions about the philosophical underpinnings of the flawed republic, questions that threaten to detonate and destroy the intellectual foundations of the country. But in addition to struggling with how to deal with those conflicting threads in his

Department of English, University of North Carolina, Chapel Hil. Email: graham@unc.edu.

${ }^{\text {I }}$ Bill E. Lawson and Frank M. Kirkland, "Introduction," in Frederick Douglass: A Critical Reader, ed. Lawson and Kirkland (Malden: Blackwell Publishers, 1999), 3, emphasis in original. 
personal life, his political career, and his role as a racial ambassador, Douglass was also interested in interrogating the contradictions of the American experiment as they were embodied in the physical landscape of the most contradictory point of the country: Washington, DC. In short, Frederick Douglass was not just a theorist but specifically an urban theorist, one who thought deeply about Washington's symbolic role and articulated a way for the city to move beyond its slaveholding past and become the literal embodiment of the promises of America.

The final decades of Douglass's career-the Washington years - have received relatively little attention from scholars; John Muller's 20 I 2 book Frederick Douglass in Washington, D. C.: The Lion of Anacostia appears to be the first of the hundreds of volumes published on Douglass to focus primarily or exclusively on that period of Douglass's life. The reasons for this inattention are obvious; Douglass won few political battles in his last decades, received political appointments far below what he and his biographers believed was his due, and took a number of positions (such as disapproving of the "Exoduster" migration to the Mid-west) that were unpopular with many blacks. ${ }^{2}$ Nevertheless, his grasp of the political and social realities of DC remained striking, and his I 877 speech "Our National Capital" articulated a cosmopolitan vision for the city which revised and updated the original dreams for D. C. to create a space which could repudiate the slaveholding past of the country and its capital city. ${ }^{3}$ Douglass was, like the capital's designer Pierre-Charles L'Enfant, a cosmopolitan thinker who believed that

\footnotetext{
${ }^{2}$ Douglass's views on post-abolition integration are complicated and resist easy characterization. Eric J. Sundquist, "Introduction," in Sundquist, ed., Frederick Douglass (Cambridge: Cambridge University Press, 1990), 17-18, puts it like this: "He was critical of the ideology of race pride or black separatism (which he feared would foster segregation), but he never lost the capacity to define freedom in demanding terms and to promote recognition of a dignified, separate African-American cultural tradition." Waldo E. Martin Jr., The Mind of Frederick Douglass (Chapel Hill: The University of North Carolina Press, 1984), is slightly harsher, nothing that Douglass believed in "racial equality" but "cultural hierarchy" - although all the races were equal at a fundamental, biological level, certain cultures were superior, and in this case Anglo-American culture was superior to African American culture (at 224). This meant that African Americans (and other races) had to assimilate to bring about Douglass's cosmopolitan utopia, which entailed a "heavy cost" which many of Douglass's contemporaries thought was not necessary to pay. Gene Andrew Jarrett, Representing the Race (New York: New York University Press, 20II), is harsher still, lumping Douglass in with Booker T. Washington as figures who "misunderstood and deeply wronged" their race (Jarrett is quoting Douglass's own words against him.) Jarrett concludes that "The countless ways that elite African American writers failed to speak accurately on behalf of their imagined African American constituents suggest that their representations of the race have just as often been acts of misrepresentation" (at 69).

${ }^{3}$ The speech was actually originally given in 1875 in Washington, DC, when it received very little attention; Douglass gave it again in 1877 in Baltimore, at which time it sparked controversy in the capital and numerous calls for the Douglass's dismissal from his post as US
} 
the organization of a people into a National body, composite or otherwise, is of itself an impressive fact ... It implies a willing surrender and subjection of individual aims and ends, often narrow and selfish, to the broader and better ones that arise out of society as a whole. ${ }^{4}$

Crucially, Douglass updated cosmopolitanism to go beyond overcoming sectional differences and into overcoming racial ones: "I want a home here not only for the negro, the mulatto and the Latin races, but I want the Asiatic to find a home here in the United States, and feel at home here, both for his sake and for ours."s But although Douglass introduced the category of race, his concerns otherwise largely overlapped with L'Enfant's; the problem for both of them was the gulf between southern and northern cultures, and the solution was the creation of a grand, unified city. In the i 877 "Our National Capital" speech, Douglass articulated a cosmopolitan vision of DC that included a plan to reshape the city to reflect the nation's composite nature. Although the speech is normally remembered not for its content but for the brief opposition it aroused to Douglass's assumption of his position as US marshal, it is in fact the culmination of a long trend in Douglass's thinking about the capital. ${ }^{6}$

Of course, DC was only one in a chain of cities where Douglass lived, worked, and theorized. If it is true, as Fionnghuala Sweeney writes, that " $\mathrm{f}]$ or slave narratives in particular the politics of resistance was early linked to the politics of location," then it is important to remember that Douglass's career of resistance was almost exclusively an urban one. ${ }^{7}$ Although Douglass is probably

marshal for the district. Most historians have suggested that Douglass's recent appointment as marshal was the reason why the speech was controversial in I 877 but ignored in 1875; Carl Abbot, Political Terrain (Chapel Hill: University of North Carolina Press, 1999), 58, has additionally suggested that in 1877 , after the end of Radical Reconstruction, "many white Washingtonians and sympathizers were far less willing to hear criticism of Washington's southern character."

${ }^{4}$ Frederick Douglass, "Our Composite Nationality," in The Frederick Douglass Papers, Series One: Speeches, Debates, and Interviews, ed. John W. Blassingame and John R. McKivigan, Volume IV (New Haven: Yale University Press: 1991), 24I. 5 Ibid., 252.

${ }^{6}$ For example, here is the entire gloss of the speech's content in William S. McFeely's excellent biography of Douglass: "Resorting to his old platform tricks of mimicry and sarcasm, he made fun of the white old guard of Washington's embarrassingly long slaveholding days." William S. McFeely, Frederick Douglass (New York: W. W. Norton \& Company, I991), 292. Here McFeely is focussing on the controversial, satirical aspects of the speech which received the vast majority of the attention in 1877 . Douglass himself protested that contemporary responses to the speech ignored the true, and truly positive, import of the speech, but at this time historians seem to have deemed the misguided response more important than the speech itself. McFeely writes, "The speech was widely reported, and a petition calling for Douglass' removal, and signed by a hundred businessmen, soon reached President Hayes." Sarah Luria's chapter on Douglass in her book Capital Speculations (Lebanon: University of New Hampshire Press, 2005), is one of the most sustained treatments of Douglass's time in Washington, but Luria does not even mention the speech.

${ }^{7}$ Fionnghuala Sweeney, Frederick Douglass and the Atlantic World (Liverpool: Liverpool University Press, 2007), 3. 
best remembered now for his depiction of plantation life in Narrative of the Life of Frederick Douglass, a fuller view of Douglass's life reveals that it was a series of urban sojourns. Without his time in Baltimore, Douglass would never have started on the track that led to his fame and freedom; if he had remained a slave in rural Maryland, no one would now know the name of Frederick Douglass. It was in Baltimore that he learned to read, that he learned of the struggle for abolition, and from his contacts in Baltimore that he put together his successful escape plan. Since his plan involved posing as a free sailor and taking a train to the North, it was only from such an industrial node, connected to the wider world by both sail and rail, that such an escape was possible. From Baltimore, Douglass established himself in a pair of urban communities, first in New Bedford, then in Rochester. In between, Douglass traveled throughout the British Isles, enlisting British and Irish support in the abolitionist cause and experiencing, according to his letters, true social equality for the first time. In this understanding of his career, Douglass's years in DC (first in a house near the capital, then on his Cedar Hill estate in Anacostia), are the fulfillment of his urban journey.

In fact, it was in the cities of Britain and Ireland where Douglass came into his own as an activist and advocate. ${ }^{8}$ Douglass's newfound self-confidence came in large part from his realization that in the cities of the British Isles, race prejudice did not exist. As he wrote in a letter to Garrison,

One of the most pleasing features of my visit, thus far, has been a total absence of all manifestations of prejudice against me, on account of my color. The change of circumstances, in this, is particularly striking. I go on stage coaches, omnibuses, steamboats, into the first cabins, and in the first public houses, without seeing the slightest manifestation of that hateful and vulgar feeling against me. I find myself not treated as a color, but as a man - not as a thing, but as a child of the common Father of us all. ${ }^{9}$

With his ever-keen grasp of irony, Douglass noted in My Bondage and My Freedom that he had found a "refuge from Republican slavery in monarchical England.” ${ }^{\circ}$ In his eventual career in Washington, DC, Douglass's goal would

${ }^{8}$ As William McFeely, "Visible Man: Frederick Douglass for the I990s," in Alan J. Rice and Martin Crawford, eds., Liberating Sojourn: Frederick Douglass and Transatlantic Reform (Athens: University of Georgia Press, I 999), I 5-30, I 5-16, writes, "It would be equally easy to demonstrate how important Frederick Douglass's trip was in the development of his selfconfidence. As he spoke in Cork, Belfast, Glasgow, Edinburgh, Birmingham, London, Bristol, and a remarkable number of other cities in between, he became triumphantly sure of himself. It was here in the British Isles, as Nathan Huggins observed, that he truly became "his own man."

9 "To William Lloyd Garrison, Dublin, Sept 16, 1 845," in The Life and Writings of Frederick Douglass: Early Years, $1817-1849$, ed. Philip S. Foner (New York: International Publishers, I950), I I 8-20, I 20.

${ }^{10}$ Frederick Douglass, My Bondage and My Freedom, Autobiographies (New York: Library of America, I 994), 370. 
be to remove the irony of "Republican slavery," the irony that Lawson and Kirkland located as the central problematic of his intellectual career. If the US was to live up to its ideals, its urban spaces would need to be sites of Republican freedom and democratic liberty; its governmental structure and its social environments needed to be aligned. DC was thus the perfect place to create a new social and physical landscape that would overcome this founding irony. Douglass finished his life and career in Washington because it was the city where the distance between the nation's ideals and realities was most evident, and also where the most could be done to bring them together. "Our National Capital" provided a rhetorical vision for an overdue, progressive updating of Pierre L'Enfant's original plan for the national city. L'Enfant's original vision was of a grandiose, cosmopolitan city symbolic of the new republic and untouched by sectional conflicts. In contrast to this vision, antebellum DC was a festering sore for anti-slavery activists and a source of constant sectional conflict: it was a monument to the freedom of all mankind, built and staffed by slaves. The schism between the goals of the American experiment and the tragic history of American slavery was reflected in the city's landscape. As Christopher Sten explains, "As the nation's capital, situated near the northern rim of the slave states that made up the old South, Washington has always had a complex, conflicted character, split along several related fault lines - national/local, northern/southern, slave/free, white/black, urban/ rural, conservative/liberal." I These fault lines came from the city's ungainly placement between regions; Carl Abbott writes, "Washington was born in a regional borderland that was itself pulled among alternative futures at the start of the nineteenth century." ${ }^{2}$ Washington was from the start a site of regional conflict, disputed territory along all the lines of demarcation laid out by Sten. In order to best understand Douglass's articulation of a postbellum version of the city which could transcend all of those fissures, we shall turn to PierreCharles L'Enfant's original attempt to design such a cosmopolitan space, then see how antebellum Washington resisted that plan.

Although L'Enfant's design is now celebrated, in the nineteenth century DC symbolized everything that was wrong about grand plans. L'Enfant's vision and the reality of Washington did not come close to meeting one another for more than a century. As we shall see, L'Enfant wanted the city to be everything that southern communities were not - centralized, organized, grandiose, and cosmopolitan. ${ }^{13}$ That grand design, however, immediately met

${ }^{11}$ Christopher Sten, "Introduction," in Sten, Literary Capital: A Washington Reader (Athens: University of Georgia Press, 201 I ), 3.

${ }^{12}$ Carl Abbott, Political Terrain (Chapel Hill: University of North Carolina Press, 1999), 3.

${ }^{13}$ It is true that certain pre-Washington cities, such as Philadelphia and even the southern port cities of Savannah and Charleston, had colonial-era grids that directed development and 
the local reality: most of those who lived in DC were southerners, and the organic culture that grew up in the city thwarted L'Enfant's design. ${ }^{14}$ DC was, according to Douglass, a Virginian city even after the Civil War. In the eyes of many northerners it was everything wrong with the South: ragged, provincial, disorganized, and slaveholding. ${ }^{\text {s }}$ Perhaps the most famous description along these lines comes from Henry Adams's The Education of Henry Adams; Henry writes of his first trip to the capital: "Slavery struck him in the face; it was a nightmare; a horror; a crime; the sum of all wickedness! Contact made it only more repulsive. He wanted to escape, like the negroes, to free soil. Slave States were dirty, unkempt, poverty-stricken,

provided a larger structure for the community. None of those, however, exhibited the kind of large-scale, blank-canvas planning of the kind which L'Enfant attempted.

${ }^{14}$ Even in 1880 , after the massive expansion of the federal government and the increase in the size of the city to 178,000 people (from 75,000 in 1860 ), the population remained southern. Leaving out the foreign-born population of the city in 1880 : "of the Americans, 53.9 percent had been born in the District, another 25 percent came from Southern states (almost all from Maryland and Virginia), and only 20.9 percent came from the rest of the United States." Michael O'Brien, Henry Adams and the Southern Question (Athens: University of Georgia Press, 2005), 51-52. If we count those born in the District in the mid-nineteenth century as southerners, then $80 \%$ of DC's population in 1880 had southern roots. Furthermore, antebellum Washington was controlled both politically and socially by southerners: "As in the previous generation, southerners held a firm grip on the national government through the I 840 s and effectively controlled the Democratic administrations of Franklin Pierce and James Buchanan"; further, "Reinforcing the southern tone of official politics was an easy social alliance of Tidewater families and southern politicians." In short, "By the I 850 os both northerners and southerners saw Washington as the first southern city on the road southward from New York and Philadelphia, the last southern city on the way north" (Abbott, 64, 65,66 ).

${ }^{15}$ A great deal of scholarship in the last half-century has challenged this view of the South as ragged and provincial. Although there is no doubt that the South was less urbanized than the North, Michael O'Brien, Rethinking the South (Baltimore: Johns Hopkins University Press, 1988), 34, points out, "Outside of the Northeastern United States and England, the South was the most urbanized culture in Western society." We have already seen that Savannah and Charleston had plans that produced beautiful and organized city centers long before New York had its grid. Furthermore, the southern urban elites especially were quite similar to and linked with the northern urban elites. These elites "made their urban milieu distinctive from the countryside and more similar to cities elsewhere. In a section rampant with ironies, southern cities had stronger economic ties and were more similar to northern cities on the eve of the civil war than at any other time." David R. Goldfield, "Cities in the Old South," in Blaine A. Brownwell and David R. Goldfield, eds., The City in Southern History (Port Washington: Kennikat Press, 1977), 52-91, 63. As Daniel Kilbride, "The Cosmopolitan South," Journal of Urban History, 26 (2000), 563-90, 564, puts it, these elites, southern and northern alike, "longed for the amenities, cultural contacts, and excitement" of cities and found them not just in Philadelphia and New York but also in "Charleston, Savannah, and Natchez." But although Kilbride is correct when he writes, quoting Michael O'Brien, that from our twenty-first century vantage point, "Few today subscribe to the notion that southern life was 'superficial, unintellectual, obsessed by slavery and race, [and] enfeebled by polemic" (ibid., 563), we will see that such a view was alive for many antebellum and postbellum writers such as Douglass and Henry Adams. 
ignorant, vicious!" ${ }^{6} 6$ Technically these observations were not made about a slave state, but rather a stretch of Washington along F Street. L'Enfant sought to give DC the social, aesthetic, and spatial unity that a metropolis needs, but antebellum observers like Adams lumped it in with the slave states and viewed it as "unkempt." It was not until the postbellum period that DC began to resemble L'Enfant's vision, and Douglass in particular dreamed of Washington as an integrated American metropolis, a muscular, masculine city driven by freed black labor.

This article will continue with a consideration of L'Enfant's plan and the engineer's desire to create a city that would not only reflect but also shape the newly born country's patriotic national character. From there, an antebellum interlude will briefly analyze accounts of the city in the decades between its founding and the Civil War, particularly using Eastman Johnson's famous i 859 painting Negro Life at the South (also known as Old Kentucky Home) to show how antebellum observers of the city saw it as a southern city rather than a northern or national space. The following section will show that the failures of L'Enfant's plans and DC's perceived southernness represented challenges to Douglass's dream of a new American national character. That section will show that in "Our National Capital" Douglass describes DC as having been doubly corrupted by slavery and by federal largesse. Douglass sees the only hope for the city in the repudiation of southernness and a transformation to an honest, northern economy built on free labor, particularly the labor of blacks. In Douglass's conception, a northern city and a national, cosmopolitan metropolis are synonymous, and represent a rebuke both to southern slaveholding and to the southern economic system.

\section{PART I: L'ENFANT'S PLAN: BUILDING UNITY OUT OF SECTIONAL DIVERSITY}

As a deliberately preplanned metropolis, DC was designed to go from more or less uninhabited to a major city by adherence to a single coherent vision. The visionary was Pierre Charles L'Enfant, an architect and civil engineer who served as an army engineer with George Washington in the Revolutionary War and was selected by Washington to design the capital city in $179 \mathrm{I}$. Although L'Enfant was relieved of his duties as city planner in I792, his design for the city - particularly his "Grand Avenue" (the future National Mall) and the spatial relationship between what would be known as the Capitol and the White House - nevertheless provided the underlying basis and structure

\footnotetext{
${ }^{16}$ Henry Adams, The Education of Henry Adams (Boston: Mariner Books, 2000), 44.
} 


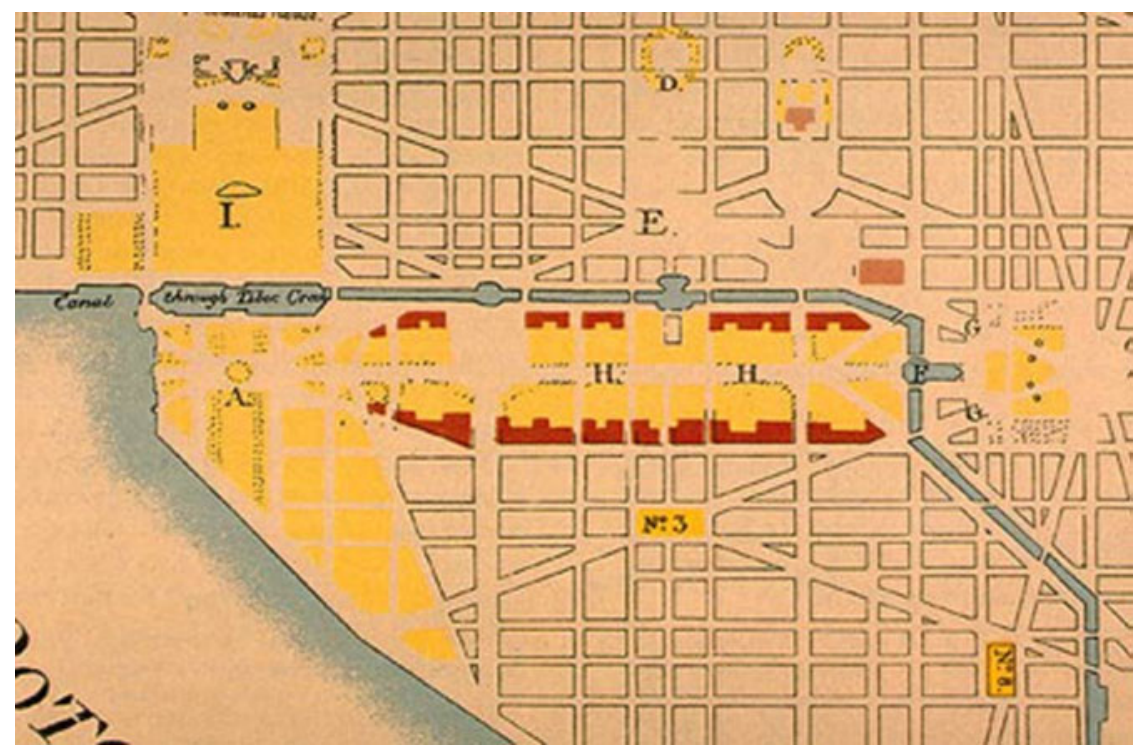

Figure i. Detail of L'Enfant's Plan, i791.

for DC. L'Enfant's plan (Figure I) for a gridded city, interrupted by avenues at 45 degree angles, and an L-shaped corridor of federal buildings, anchored by the Capitol and the White House, did endure (although the Mall was later expanded into a cruciform). Although the plan was never fully implemented, the idea of the plan endured in the nineteenth century and into the twentieth century. At first it was remembered as a failure, a skeleton that was laughable by virtue of having never been given flesh. By the end of the nineteenth century, however, it had become a beautiful vision that had gone tragically unrealized.

L'Enfant's plan was meant to simultaneously reflect the greatness of the United States and create aspects of that greatness. The two ideals which L'Enfant saw as crucial to both the country and its capital city were grandeur and unifying coherence. L'Enfant wanted the city to be an overwhelming, even sublime, testament to the greatness of the United States - his original design for the "Presidential Palace" called for it to be five times larger than the building that was actually built. His other goal was that the city be unified, a coherent entity which adapted itself to its river surroundings but was deliberately centered on the Capitol. Indeed, L'Enfant went so far as to designate the longitude of the Capitol to be o:o. The DC of L'Enfant's plan was thus forward-looking and constructive, dictating the future of the nation more than reflecting its embryonic present. As L'Enfant wrote in the conclusion to the memoir which accompanied 
the plan when he presented it to President Washington and assorted cabinet members,

as I remain assured you will conceive it essential to pursue with dignity an undertaking of a magnitude so worthy of the concern of a grand empire, I have not hesitated to express myself freely, realizing that the nation's honor is bound up in its complete achievement and that over its progress the nations of the world, watching with eyes of envy, themselves having been denied the opportunity, will stand as judge. ${ }^{17}$

As the emblem of a cosmopolitan nation, the grandeur of L'Enfant's dream city is less important that its emphasis on unity, coherence, and proximity. In a report to President Washington, L'Enfant wrote,

Having determined some principal points to which I wished to make the others subordinate, I made the distribution regular with every street at right angles, North and South, east and west, and afterwards opened some in different directions, as avenues to and from every principal place ... principally to connect each part of the city, if I may so express it, by making the real distance less from place to place, by giving to them reciprocity of sight and by making thus seemingly connected, promote a rapid settlement over the whole extent, rendering those even of the most remote parts an addition to the principal ${ }^{18}$

L'Enfant's first goal was to establish "principal points" in the city to which all other points would be subordinate. Just as he imagined the nation's capital to be the center of the country, he wanted DC's Capitol building and Presidential Palace to be a pair of central points around which the rest of the design would be filled in.

The true genius of the plan, however, was the radiating avenues that L'Enfant used to create and connect the most important points of his city. If only the Capitol, President's House, and the "Grand Avenue" (the future National Mall) had broken the rigid network of streets, the result would have been a densely gridded city situated around a largely inaccessible center. L'Enfant's radiating avenues not only added variation and beauty to the city plan by "contract[ing] with the general regularity" and affording "pleasant prospects," but they also "connect each part of the city." In L'Enfant's plan (Figure I), the radiating avenues establish a line of sight between the President's House and the Capitol - as in Pennsylvania Avenue - as well as various lines of sight between those two buildings and the Potomac, the outskirts of the city, and even the other squares and circles which the avenues create when they intersect one another. ${ }^{19}$ The result is a city that combines the

${ }^{17}$ Pierre-Charles L'Enfant, "Plan of Washington, D. C.," in Elizabeth Kite, ed., L'Enfant and Washington 1791-1792: Published and Unpublished Documents Now Brought Together for the first time (Baltimore: Johns Hopkins University Press, 1929), 7 I.

${ }_{18}^{8}$ Ibid., 53 .

${ }^{19}$ Those squares were named for the fifteen states then in existence, thus could also symbolize the republican nature of the nation's power; as James H. S. McGregor explains in Washington 
structure of a grid with the openness of avenues; L'Enfant designed these avenues to "make the real distance" between these points "seem less from place to place." DC, in L'Enfant's plan, is thus a city of connected nodes, oriented around the buildings that house federal power. In this way the city would reflect the nation, encouraging each area of the city to think of itself as part of the larger whole and imagine itself as closer to the center than it actually was. In the plan, as in the nation, even "the most remote parts" of the city are part of the whole, an "addition to the principal" - each piece of the city is wholly and fully a part of the larger metropolis, even if it is subordinated to the central powers. L'Enfant also thought that this trick of reducing distance and uniting the outskirts with the center would lead the plan to be realized faster, as a rigid grid would have made the outskirts of the city seem like hinterlands, but the feeling of proximity and unity granted by the avenues would make the outer areas as desirable for settlement as the center. This turns the capital into a microcosm of L'Enfant's vision of a republican empire, in which even the outermost states conceive of themselves as fully part of the empire centered on DC.

L'Enfant did not just want the city to resemble the United States in its grandeur and unity; he wanted the capital to actually shape the character of the nation. In a letter to Alexander Hamilton, L'Enfant wrote,

I earnestly wish all that the Eastern States can spare may come this way, and believe it would answer as good a purpose as that of their emigration to the West. It would deface that line of markation which will ever oppose the South against the East, for when objects are seen at a distance the idea we form of them is apt to mislead us ... and we fancy monstrous that object which, from a nearer view, would charm us ... Hence arises a natural though unwarrantable prejudice of nations against nations, of States against States, and so down to individuals, who often mistrust one another for want of being sufficiently acquainted with each other. ${ }^{20}$

Prophetically, L'Enfant suggests that the same prejudices that operate between nations will come to operate in the United States. The North (or "the East") and the South will, he fears, eventually accept a caricatured view of one another due to their lack of proximity, and the result will be a generalized mistrust. L'Enfant's solution to this problem is Washington, DC as a transformative melting pot. Instead of leaving the established states to settle in the uninhabited wilderness to the west, L'Enfant believes that the surplus population of the northeastern states should move south to DC and settle the

from the Ground Up (Cambridge, MA: Belknap Press of Harvard University Press, 2007), 34, the "constellation of state squares, bound together by the avenues radiating from the central buildings, represent the United States as a confederation."

${ }^{20}$ Pierre-Charles L'Enfant, quoted in J.J. Jusserand, "Introduction," to Kite, L'Enfant and Washington $1791-1792, \mathrm{I}-30, \mathrm{I} 6$. 
wilderness that he is transforming into a capital city. By doing so, those residents will bring their northeastern habits and attitudes with them, and, when they interact with the southern residents of Virginia and Maryland, both groups will be able to move past their mistaken prejudices. DC would thus serve as a point of union and communion for the country, radiating interregional understanding to its different portions. In L'Enfant's plan, DC would be a regional melting point, creating a new national character by virtue of its inclusive geography.

\section{INTERLUDE: ANTEBELLUM FAILINGS}

The Civil War was precisely the outcome that L'Enfant sought to avoid. But we will never know if L'Enfant's scheme would have forestalled it. L'Enfant's dream of a grandiose and coherent city was not realized in his lifetime, and was not even substantially realized until the second half of the nineteenth century at the earliest. A series of foreign observers bore witness to the fact that the grand city had not come to be. Observing the Grand Avenue connecting the Capitol and the Presidential House in 1797, François Alexandre Frédéric, duc de La Rochefoucauld-Liancourt, wrote, "The plan is fine, cleverly and grandly designed, but it is its very grandeur, its magnificence, which causes it to be nothing but a dream." ${ }^{21}$ In the duke's reading, L'Enfant's mistake was designing such harmonious grandeur; any deviations from the plan that L'Enfant drew up are immediately obvious when a less grand plan might have been more flexible. Charles Dickens praised aspects of Washington during his I 842 US visit, writing that on his trip into the city he "had upon the way a beautiful view of the Capitol, which is a fine building of the Corinthian order, placed upon a noble and commanding eminence." 22 Once inside the city, however, Dickens realized that the Capitol was an exception. He famously described DC as a "monument to a deceased project" and painted this image for his European audience:

Take the worst parts of the City Road and Pentonville, preserving all their oddities, but especially the small shops and dwellings, occupied there (but not in Washington) by furniture-brokers, keepers of poor eating-houses, and fanciers of birds. Burn the whole down; build it up again in wood and plaster; widen it a little; throw in part of St. John's Wood; put green blinds outside all the private houses, with a red curtain and a white one in every window; plough up all the roads; plant a great deal of coarse turf in every place where it ought not to be; erect three handsome buildings in stone and marble, anywhere, but the more entirely out of everybody's way the better; call one the Post Office; one the Patent Office, and one the Treasury; make it scorching hot in the

${ }^{21}$ Duc de la Rouchefoucault Liancourt, quoted in Jusserand, 28.

${ }^{22}$ Charles Dickens, American Notes for General Circulation (London: Penguin Books, 2000), I 28 . 
morning, and freezing cold in the afternoon, with an occasional tornado of wind and dust; leave a brick-field without the bricks, in all central places where a street may naturally be expected: and that's Washington. ${ }^{23}$

Dickens's description is a total reversal of L'Enfant's vision. Dickens compares DC to the ragged outskirts of the world's major metropolises, not the great centers that L'Enfant studied. But more importantly, whereas L'Enfant wanted to create a unified plan in which a series of avenues linked the city into a whole, Dickens takes the defining feature of DC to be the way that nothing fits together the way it should. The private buildings look like poor London eating-houses that have been burnt down and then badly rebuilt with inferior materials, while the public buildings, made of handsome stone and marble, seem not only out of place with their surroundings but unconnected to the rest of the city. The governmental buildings might be out of the way, but the grass seems to be in the way, and there are brick-fields without bricks everywhere a street should be, and what streets there are seem to have been plowed up. Nothing could be further from L'Enfant's vision of a monumental city with no outskirts; in Dickens's reading, the city is nothing but outskirts. As with La Rochefoucauld-Liancourt, Dickens was struck by the utter incongruity between the actually existing DC and L'Enfant's grand plan:

It is sometimes called the City of Magnificent Distances, but it might with greater propriety be termed the City of Magnificent Intentions; for it is only on taking a bird's-eye view of it from the top of the Capitol, that one can at all comprehend the vast designs of its projector, an aspiring Frenchman. Spacious avenues, that begin in nothing, and lead nowhere; streets, mile-long, that only want houses, roads and inhabitants; public buildings that need but a public to be complete; and ornaments of great thoroughfares, which only lack great thoroughfares to ornament - are its leading features. ${ }^{24}$

Another French observer, Jean-Jacques Ampère, viewed the city a decade after Dickens and, despite the fact that DC had improved in the interim, described a similar situation to the one that confronted Dickens ("streets without houses and houses without streets"), and concluded that the mid-nineteenth-century state of DC was "a striking proof of this truth that one cannot create a great city at will." ${ }^{25}$ La Rochefoucauld-Liancourt, Dickens, and Ampère all agree that L'Enfant's plan served as proof that cities cannot be planned in that manner, and that DC had no chance of becoming a metropolis worthy of a grand empire.

If antebellum DC failed to realize L'Enfant's vision for an imposing and unified capital, it failed just as spectacularly to serve as a cosmopolitan meeting ground for America's sectionally divided citizens. Both failures are particularly obvious when we turn to Eastman Johnson's famous i 859 painting Negro Life

\footnotetext{
${ }^{23}$ Ibid. $\quad{ }^{24}$ Ibid., I $29 . \quad{ }^{25}$ Jean-Jacques Ampère, quoted in Jusserand, 28.
} 


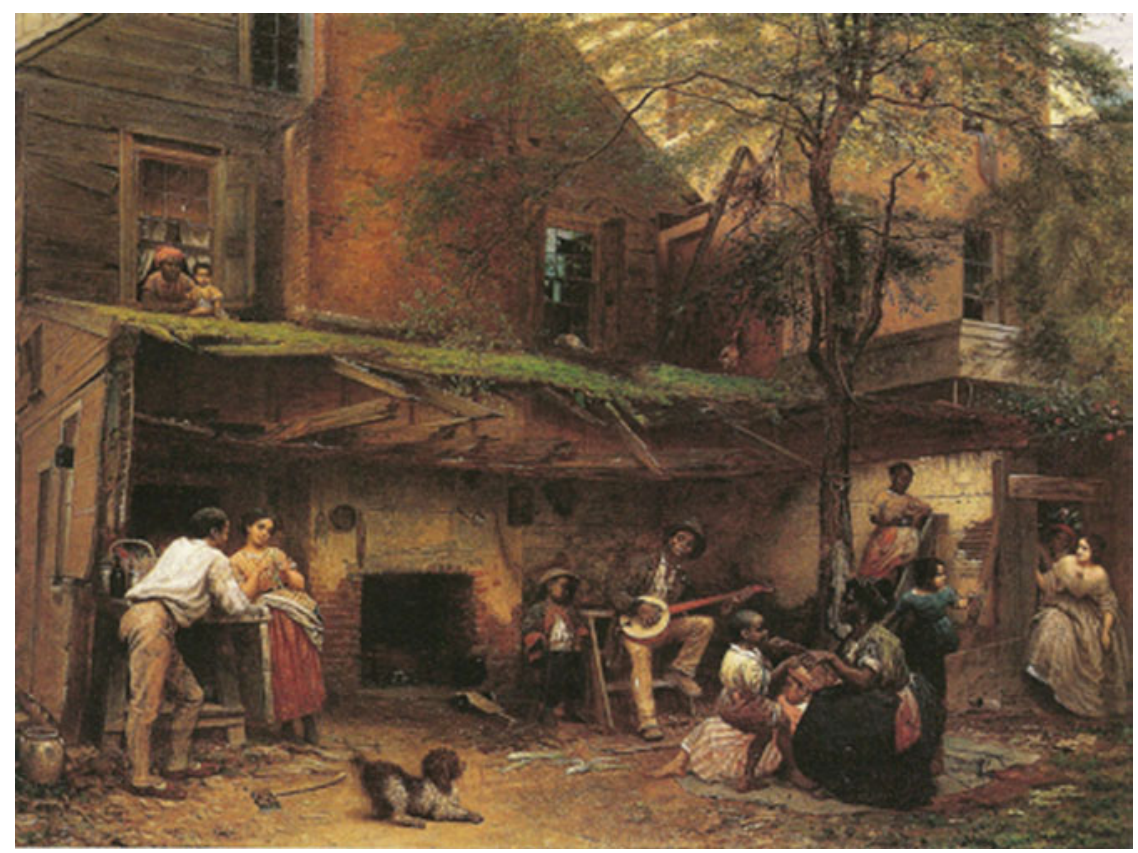

Figure 2. Eastman Johnson's Negro Life at the South.

at the South (Figure 2). Negro Life depicts the back courtyard of a southern home, in which a number of blacks and one white woman are arranged around a black man playing the banjo. In its popular reception, Negro Life was immediately received as a depiction of slave life: "Like the long-running dramatizations of Stowe's Uncle Tom's Cabin, the painting presented a panorama of episodes of life under slavery in a way meant to remind the viewer of the humanity of African Americans while also hinting at the more 'pathetic' aspects." ${ }^{26}$ Whether or not Johnson was depicting his African American figures as suffering is a matter of some debate; most of the figures listening to the banjo seem to have a slight smile or otherwise placid expression on their faces, but this indicates at best a lack of immediate, overt suffering. The banjo player himself has an inscrutable expression, onto which the viewer can project mild contentment or resigned suffering, among other emotional states. But although the debate about the inner state of mind of the figures is ongoing, there is no denying the general dilapidation of the scene. The courtyard itself was clearly not originally intended to be a courtyard, but was in fact a part of

${ }^{26}$ Patricia Hills, “Painting Race: Eastman Johnson's Pictures of Slaves, Ex-slaves, and Freedmen," in Teresa A. Carbone, ed., Eastman Johnson: Painting America (New York: Rizzoli International Publications, 2000), I 26. 
the house which has subsequently been razed; portions of its walls remain where it shared those walls with the surrounding structures, but its back wall is gone and its roof is mostly absent, with ragged roof beams jutting out over the banjo player's head. A hatchet and a watering pot lie discarded on the ground, amidst other assorted bric-a-brac, and even the portions of the house that remain intact are in disrepair, with boards coming loose in the upper left-hand corner of the painting. A house to the right of the courtyard seems to have a stucco finish in much better repair, and from this considerably more prosperous-looking home emerges the painting's only white figure. That woman's tasteful beige dress, with its exposed shoulders, fashionable bodice, and ruffled petticoat, forms a clear contrast to the dress of the African Americans in the scene, whose outfits are generally in primary colors and include features such as bandanas (as in the women taking care of the children in the bottom right and top left of the painting), aprons (as in the girl on top of the stepladder in the bottom right), or an exposed red petticoat (as in the woman in the bottom left of the painting). While the debate raged then and rages now as to whether Negro Life at the South depicts suffering, ${ }^{27}$ the painting does make clear the gap in living conditions between the black figures and a white woman who seems to be at least middle-class, and also could be the owner of the ambiguously depicted black figures.

Although pro- and anti-slavery figures disagreed as to whether or not it depicted the horrors of slavery, there was wide consensus that the painting was a typical depiction of southern slave life, full of classic types similar to those established in popular culture. As John Davis tells us, contemporary viewers of the painting immediately grouped it with other depictions of slave life, "particularly Harriet Beecher Stowe's Uncle Tom's Cabin." ${ }^{28}$ Davis continues, "The most enduring popular association, however, was with Stephen Foster's sentimental minstrel song 'My Old Kentucky Home, Good Night!',"29 and indeed the painting was almost immediately better known by the alternate title Old Kentucky Home, an association that continued well into the twentieth century. The painting is masterfully composed and executed, but its portrait of black life - a heterogeneous (male and female, young and old, light and dark) group of people taking pleasure in music and in each other amidst dilapidated surroundings and domesticated and farm animals - was taken to be to be a standard slice of southern slave life. In fact, the painting depicts not

${ }^{27}$ John Davis, "Eastman Johnson's Negro Life at the South and Urban Slavery in Washington, D.C.," Art Bulletin, 80 (1998), 67-92, 67, notes that the painting has a reputation for "its ability to be all things to all people." Abolitionists saw the "moral degeneracy of the institution of slavery" in the "decrepit, tumbledown living conditions," while "slavery's defenders" saw "the careless leisure-time activities of several generations of slaves provided visual proof that forced servitude was neither physically onerous nor destructive of family life."

${ }^{28}$ Ibid., 70.

${ }^{29}$ Ibid. 
a plantation in Kentucky but an urban space in the District of Columbia. Whereas L'Enfant imagined his DC as a radically different kind of city, neither northern nor southern, Johnson's painting shows that 1859 DC was in many ways just another southern city. On the eve of the Civil War, just as DC was about to become the capital of the Union North, contemporary observers could not tell L'Enfant's DC from Jefferson Davis's Kentucky.

\section{PART III: FREDERICK DOUGLASS'S NEW BLACK DC}

Although L'Enfant's plan was a failure in one sense, from another perspective it was an unmitigated success. L'Enfant and his patron, George Washington, dreamed of a city that would reflect the reality of the nation. As Sarah Luria puts it:

The city was designed to help fulfill the constitution, ratified just four years before: not only would the city serve as home to the national government, it would provide a site where the abstract concept of the nation could be experienced as a physical reality - something a citizen could point to, visit, and admire. ${ }^{3 \circ}$

Although the city was not admirable, it was a rousing success at serving as a physical space that could represent both the Constitution and the nation as a whole. Gloriously designed but incompetently executed, riven by sectionalism, controlled by a southern faction, dedicated to liberty but besmirched by slavery: DC did not represent the nation that President Washington dreamed of, but it uncannily captured the actual state of the country. This last reality - the physical instantiation of liberty's ideals having been constructed by slaves - was seen by many as DC's most obvious symbolic function. In his narrative of being enslaved, Solomon Northup highlights this incongruity in his description of the slave pen he was held in in Washington: "Strange as it may seem, within plain sight of this same house, looking down from its commanding height upon it, was the Capitol. The voices of patriotic representatives boasting of freedom and equality, and the rattling of the poor slave's chains, almost commingled." ${ }_{31}$ This "strange" juxtaposition is not strange at all, but the logical spatial and aural consequence of the conflicted constitution.

Herman Melville's satirical depiction of DC is even more pointed in its conflation of the Capitol's grandiosity and the nation's failings:

"Ha, ha, my fine fellow! We are all kings here; royalty breathes in the common air. But come on, come on. Let us show you our great Temple of Freedom."

${ }^{30}$ Luria, Capital Speculations, xxxiii.

${ }^{31}$ Solomon Northup, Twelve Years a Slave, ed. Su Eakin and Joseph Logsdon (Baton Rouge: LSU Press, I 968), 23. 
And so saying, irreverently grasping his sacred arm, they conducted us toward a lofty structure, planted upon a bold hill, and supported by thirty pillars of palm; four quite green; as if recently added; and beyond these, an almost interminable vacancy, as if all the palms in Mardi, were at some future time, to aid in upholding that fabric.

Upon the summit of the temple was a staff; and as we drew nigh, a man with a collar round his neck, and the red marks of stripes upon his back, was just in the act of hoisting a tappa standard - correspondingly striped. Other collared menials were going in and out of the temple. ${ }^{22}$

In Vivenza, Melville's allegorical US, the symbolic irony is heightened by having the Capitol named the "Temple of Freedom" but staffed by slaves. Furthermore, the reality of slavery is not just realized in physical space but also literally embodied on the backs of the slaves: the red stripes of recently inflicted wounds match the stripes of the "Vivenzan" flag.

As Douglass was dedicated to navigating and overcoming the distance between America's ideals of liberty and the lived reality of slavery, it was inevitable that his career would take him to Washington, where he spent his final decades. Douglass saw the city as the place where he could both effect the most change and become the most visible symbol of a successful African American. Christopher Sten argues that Douglass had this view of DC from very early in his life - when he first heard the word "abolitionist" - until the end of it:

Douglass retained a certain faith in the Federal Government - the executive branch, perhaps, most of all - to keep alive what Melville called the "Founders' dream" of freedom for all people. For him, Washington was still the city of hope, the place where he served his people and his country, and so it remained until the end of his life. ${ }^{3}$

Despite his belief in the power of the federal government, the later years of Douglass's career - the post-Fifteenth Amendment years - have generally been regarded as his most regrettable. At a surface level, Douglass's DC years look like a series of accomplishments; he served as the president of the Freedman's Bank, and was appointed the US marshal for DC, then the recorder of deeds for DC, and finally the US ambassador to Haiti. But there were downsides to all of these positions. The bank became insolvent and was shut down shortly after Douglass assumed his presidency, and Douglass was dogged with questions as to how much he knew and when. The marshal appointment was interpreted by many as a bribe, so that President Hayes "could pose as a champion of Negro rights while bargaining away the Negro's freedom." 34 Furthermore, the US marshal for DC had for more than a decade served the

\footnotetext{
${ }^{32}$ Herman Melville, Mardi and a Voyage Thither (Evanston and Chicago: Northwestern University Press and the Newberry Library, 1970), 5 I 4-I 5.

${ }^{33}$ Christopher Sten, "City of Hope and Fear: Melville and Douglass in the Nation's Capital," Leviathan, I 0, 2 (June 2008), 23-36, 24, 30.

${ }^{34}$ Philip S. Foner, Frederick Douglass, 2nd edn (New York: The Citadel Press, 1969), 323.
} 
unofficial role of introducing guests at the White House, but President Hayes declined to have Douglass continue this position (widely believed to be for racial reasons). The recorder of deeds appointment was a step down from marshaldom, particularly since Douglass "had great hopes that he would be rewarded with a far grander post than he had yet held." 35 And in Haiti, the Navy's desire to put a naval base at Mole St. Nicholas meant that Douglass usually played second fiddle to Admiral Bancroft Gherardi, who was authorized to "negotiate directly for the base" without having to go through Douglass. ${ }^{36}$ All of this, combined with Douglass's steadfast support for a Republican Party which was increasingly blind to the plight of freed blacks, gives proof to McFeely's assertion that "Douglass was already [in I 876] part of a dead past," little more than a tool of the Republicans who "knew there were still black voters who liked a look at him, alive." 37

This focus on Douglass's scant political accomplishments in his final years overlooks the way that he was still intellectually engaged with the project of improving the lives of African Americans, and particularly how he saw Washington as the place for that project. In postbellum Washington, Douglass saw the federal government as the only chance to make and keep the gains that the Civil War had made possible, and he wanted a federal city that reflected that new reality. As Waldo E. Martin Jr. explains, Douglass "believed human moral and mental endowments to be a function of environment and, consequently, alterable." ${ }^{8} 8$ The racism and animus of Washington, DC were not permanent features of racial conflict but the product of the historical environment. At the level of the individual, "miscegenation was natural" and could produce better-adjusted citizens, ${ }^{39}$ while at the level of the city, a new way of mixing the inhabitants had to be developed. In "Our National Capital," Douglass lays out the progress made towards this new mixed environment in the federal city. Although Douglass was attacked in the D. C. newspapers for the negative aspects of his speech, he correctly notes in this third autobiography that "I said many complimentary things of the city, which were as true as they were complimentary. I spoke of what it had been in the past, what it was at that time, and what I thought it destined to become in the future." 40 In fact, the focus of Douglass's speech is the gains made since the end of the Civil War and his future hopes for the city, not the racism and problems that remained. Douglass was in fact too kind to the city; Sarah Luria describes how Douglass, in an 1875 speech praising the its civil rights laws, lauded the city to the point where the speech "does not reflect the city's social

\footnotetext{
${ }^{35}$ McFeely, Frederick Douglass, 305. $\quad{ }^{36}$ Ibid., 347. $\quad{ }^{37}$ Ibid., 289.

${ }^{38}$ Martin, The Mind of Frederick Douglass, $198 . \quad{ }^{39}$ Ibid.

${ }^{40}$ Frederick Douglass, The Life and Times of Frederick Douglass (New York: Gramercy Books, I993), 413.
} 
reality so much as it tries to create it."41 "Our National Capital" partakes in a similar attempt at creation. But before we get to Douglass's optimistic description of the city's present and future, we can set the stage with his description of the past. Prior to recent events, "Washington, as compared with many other parts of the country, has been, and still is, a most disgraceful and scandalous contradiction to the march of civilization." 42 "Contradiction" is the word to emphasize here - the city that was meant to represent progress has instead represented oppression and backwardness. The antebellum city was not truly representative of the new country but rather was "pervaded by the manners, morals, politics, and religion peculiar to a slave-holding community, the inhabitants of the national capital were, from first to last, frantically and fanatically sectional. It was southern in all its sympathies, and national in name only." 43

This aspect of "Our National Capital" is a continuation of Douglass's earlier remarks on the capital. Prior to Reconstruction, he saw in DC the same thing that contemporary viewers saw in the Eastman Johnson painting: a standard slice of the slaveholding South. Before, during, and even after the war, Douglass was skeptical of the commitment of northern politicians to ending slavery and helping blacks, and DC particularly felt his disdain. In Douglass's telling, many, if not most, northern whites (including, originally, Lincoln) viewed the preservation of the Union as the primary goal of both antebellum politics and the Civil War, relegating abolitionist and anti-slavery goals to secondary status. Prior to the Emancipation Proclamation, Douglass doubted that such a measure would ever be passed, in part because of the culture of Washington. In a January i 862 article published in Douglass' Monthly, Douglass ferociously attacked Union opponents of abolition:

It is nothing that the slave-holding traitors acted from the beginning like a band of burglars, stealing all they could carry away, designing to burn and destroy the rest; it is nothing that they are now raging with malice and thirsting for loyal blood, defying the national power, and menacing the Capital itself ... notwithstanding all this is done from no other earthly motive than the preservation and prosperity of the infernal slave system, no man yet durst to strike the death-blow at the obvious cause of all our present domestic calamities. ${ }^{4}{ }^{4}$

In Douglass's reading, although the southern states are fighting for the dissolution of the Union and the northern states are fighting for its preservation, only the southern states have acknowledged slavery as the true

\footnotetext{
${ }^{41}$ Sarah Luria, Capital Speculations, 74.

${ }^{42}$ Frederick Douglass, "Our National Capital," in The Frederick Douglass Papers, Series One: Speeches, Debates, and Interviews, Volume IV, $454 . \quad{ }^{43}$ Ibid., 455.

${ }^{44}$ Frederick Douglass, "The Slave Power Still Omnipotent at Washington," in The Life and Writings of Frederick Douglass, ed. Philip S. Foner, Volume III (New York: International Publishers, I 952), I 85-86.
} 
root of the conflict. The northern states were taking refuge in what would later be a traditional southern argument: that the war was about the preservation of the Union and the illegality of nullification and secession, and that slavery is not the reason for battle. Douglass offers up the traditional explanation for the Union's reluctance to make the conflict primarily about slavery: the border states, slave states who must be placated to keep their Union loyalties:

For these border States our army is constantly degraded to the level of slave dogs, hunting and catching slaves; for them we are dismissing anti-slavery men from office and position in the armies, and filling their places with men who hate the Negro, and will do all they can to perpetuate his bondage. 45

But Douglass adds a less traditional cause for Union inaction on slavery: "There is still no North at the Capital. Virginia is still the Old Dominion, and she is as intensely slaveholding when represented by Carlisle $[s i c]$ as by the traitor Mason." ${ }^{46}$ In Douglass's telling, DC is Virginian, and Virginians are pro-slavery, even if they are also pro-Union, as the loyalist Senator John Carlile was. Even though the Confederate army is threatening the capital in the name of slavery, the capital is refusing to threaten slavery.

However, the tide turned quickly in terms of the anti-slavery movement. As Douglass points out in a speech in March of 1862 , just two months after the publication of "The Slave Power Still Omnipotent at Washington": "Dr. Cheever, Ralph Waldo Emerson, Gerrit Smith, Wendell Phillips, William Goodell, and William Lloyd Harrison may now utter in safety their opinions on slavery in the national capital. Meanwhile Congress has a bill before it for the abolition of slavery in the District of Columbia." 47 The process of slavecatching by the army has been ended, and Lincoln has started to make overtures towards emancipation. Douglass, echoing L'Enfant's idea for a nation tightly wrapped around a federal center, says, "Kill slavery at the heart of the nation, and it will certainly die at the extremities." ${ }^{48}$ Douglass was one of the key voices in the fight for emancipation, and he was right that emancipation would slowly spread from the capital outward. That particular victory was won. But although slavery was defeated in DC and, eventually, in the rest of the country, Lee's surrender was not enough to bring "the North" to DC.

In "Our National Capital," Douglass argues that the continued vitality of Southern culture in Washington stemmed from two pernicious influences: first, and most importantly, the capital's placement between two southern, slave-holding states, which owed to the "potent influence of

45 Ibid., I 85 .

${ }^{46}$ Ibid., I 86.

${ }^{47}$ Frederick Douglass, "The War and How to End It," in The Frederick Douglass Papers, Series One: Speeches, Debates, and Interviews, ed. John W. Blassingame and John R. McKivigan, Volume III (New Haven: Yale University Press, I985), 517.

${ }^{48}$ Ibid., 5 I 7 - I 8 . 
George Washington." 49 Although Washington was a southern slaveholder, Douglass is frequently complimentary to the first President, and he takes care to register that his belief that "the selection of Washington as the National Capital was one of the greatest mistakes made by the fathers of the Republic" is stated "not so much in censure, as in sorrow." 50 But the damage was done, because the people of Washington "are mainly of the old slave holding stock of Virginia and Maryland ... The sources of their revenue were, slavery and the Government. Of Uncle Sam's good things, Virginia and Maryland always got the lion's share." ${ }^{11}$ Here is the second influence on the population of DC: federal largesse. "Everyone wants favor; everybody expects favor; everybody is looking for favor; hence everyone smiles, bows, and fawns toward everybody else." ${ }_{2}^{2}$ This political spoils-seeking works, in Douglass's description, much like slavery does: wealth is obtained without honest labor, and the result is a city whose social dealings are based on a false nicety which hides governmental corruption and a false nobility which is predicated on the suffering of slaves. Rather than opposing and counterbalancing southern sentiments, the federal government has in fact reinforced them.

Douglass argues that DC could have done what Baltimore did and overcome its heritage to become a northern city. He details all the resources that Washington had which could have made it an industrial power - coal, iron, labor, and a natural harbor. But the city never industrialized, and remained "isolated from the outside world and dependent on a single railroad" 53 due to the easy revenue sources of slavery and the federal government. ${ }^{54}$ Propped up by two systems which reward personal inactivity, the city stagnated and festered. The people of Washington can be distinguished from "the people of the north, the west, and the east" (but not the South) by their indolence.5s The symbol of the Washingtonian, as Douglass puts it with cutting satire, is the cane:

In the economy of life his muscles have had little to do, and disuse has induced a lack of ability and disposition... He generally walks with a cane, often sits toying with a

${ }^{49}$ Douglass, "Our National Capital," 454. ${ }^{50}$ Ibid. ${ }^{51}$ Ibid., 458. ${ }^{52}$ Ibid., 46 I. ${ }^{53}$ Ibid., 474.

${ }^{54}$ Again, Douglass's vision is strikingly in concert with L'Enfant and Washington's original vision. As Carl Abbot explains in Political Terrain, 28, "It was to be an eminently practical gateway to the new nation and its new empire - an improved Philadelphia, a republican London." "Anacostia docks" were meant to open the city up to the agricultural and industrial output of an entire continent but, as Abbot explains, other cities, such as Baltimore, built the canals and railroads needed to exploit that production first. Douglass is lamenting that DC did not do exactly what L'Enfant and Washington had wanted it to do. Of course, Washington was a failure as a commercial venture from the very beginning; not only did the city fail to access the wealth of the new country, but also the city itself was supposed to be a successful business venture but by 1797 had already acquired "a bad name" as "a place of investment" that would "handicap the city for years to come." Constance McLaughlin Green, Washington: Village and Capital (Princeton: Princeton University Press, 1962), 15.

s5 Douglass, "Our National Capital," 458-59. 
cane, and is seldom seen without a cane. He evidently carries it more as a mark of dignity and as a badge of authority, than as a means of support. ${ }^{56}$

The cane is paralleled in the working classes by the "black boy"; if you send for a mechanic or plumber, "at his heels you will find the inevitable black boy. He is there to carry the tools, to tote the water, and to otherwise wait and tend on the Boss." 57 Labor is foreign to the wealthy Washingtonian and lower-class Washingtonian alike. The result is a city that, despite having been deliberately planned and designed to display national unity, has never even achieved local unity because improvement projects cut against the civic ethos. These elements of the speech are what lead to calls for Douglass's dismissal from his marshal position, as the brouhaha over these insults "demonstrated how fully the growth of the nineteenth-century capital was deeply enmeshed in the national politics of drawing sectional borders," 58 sectional borders that both L'Enfant and Douglass hoped to overcome.

Douglass, in fact, argues that by i 877 they largely have been overcome:

The spade, plough, and pick-axe of the Freedman have changed the appearance of the face of the earth upon which the city stands. Hills have been leveled, valleys filled up, canals, gulleys, ditches, and other hiding places of putridity and pestilence, have been arched, drained, and purified, and their neighborhood made healthy, sweet, and habitable.

The old repulsive market places, so long a disfigurement to the city and a disgrace to the civilization of the age, have been swept away, and replaced by imposing and beautiful structures, in keeping with the spirit of progress. 59

Douglass goes on to list a whole slew of further improvements: "Magnificent thoroughfares," "splendid mansions," "street railways," "public parks," and so on. ${ }^{60} \mathrm{DC}$ is finally coming into the future, having "snapped the iron chain of conservatism which anchored the city to a barbarous past," ${ }^{\mathrm{I}}$ and the future is not only less malarious and more healthy and habitable, but also a beautiful magnificence, linked by thoroughfares and railways. The future is, in other words, L'Enfant's plan. ${ }^{62}$

Like L'Enfant, Douglass emphasizes the internal coherence of the city, the unity it finds when "the outlying tracts of land, once the broad receptacles of dead animals ... have been reclaimed and added to the city and made to blossom like the rose." ${ }_{3}$ Whereas Dickens could find no sense of order in DC,

\footnotetext{
${ }_{56}^{56}$ Ibid., 459. $\quad \quad \quad \quad{ }^{57}$ Ibid., 466, original emphasis. $\quad{ }_{58}^{58}$ Abbott, Political Terrain, 58.

${ }^{59}$ Douglass, "Our National Capital," $446 . \quad{ }^{60}$ Ibid., $447 . \quad{ }^{61}$ Ibid., 448.

${ }^{62}$ Mary Clemmer Ames makes this comparison explicit, declaring in her 1875 work Ten Years in Washington (Hartford: A. D. Worthington and Co.), 73, that the vistas of Washington have finally been realized, so that "the sight rests at last where poor Major L'Enfant dreamed and planned that it one day would." Ames, like Douglass, believes that Washington has at last become "another city neither Southern nor Northern, but national, cosmopolitan" (ibid., 72).

${ }^{63}$ Douglass, "Our National Capital," 447.
} 
the outskirts have finally been properly related to the center. But the internal unity of the city is minor compared to DC's long-awaited status as a symbol of the country's larger unity. Reviving the regional mixing aspect of L'Enfant's plan, Douglass envisions a future capital in which sectionalism has been left behind and a national identity can be born:

Elsewhere he may be a citizen of a state, no larger than Delaware; here he is a citizen of a great nation. Elsewhere he belongs to a section, but here he belongs to the whole country and the whole country belongs to him. No American now has a skin too dark to call Washington his home, and no American now has a skin so white and a heart so black to deny him that right. Under the majestic dome of the American Capitol, as truly as under the broad blue sky of heaven, men of all races, colors, and conditions may now stand in equal freedom, thrilled with the sentiment of equal citizenship and common country. The wealth, beauty, and magnificence which, if seen elsewhere, might oppress the lowly with a sad sense of their personal insignificance, seen here, ennoble them in their own eyes, and are felt to be only fit and proper to the capital of a great nation. ${ }^{64}$

In Douglass's reading, DC was once the capital of sectionalism, dominated by the old, slaveholding families whose slaves and political influence prevented them from having to work. The newly freed slaves, in contrast, are working hard to turn DC into a city without sectional divisions. Although it was a disaster that the capital was originally placed in southern territory, the efforts of the freed slaves can undo that influence and create a unified city. Anticipating efforts such as the 1893 Chicago World's Fair and the McMillan Commission's reworking of the National Mall, Douglass is arguing that DC can be a place where every American ${ }^{65}$ - of any race, color, and condition can view the monumental achievements of the city as something that he has a claim to. The same Capitol building which once served as a symbol of wealth and of the preeminence of slave power has, through the labor of freedmen,

${ }^{64}$ Ibid., $45 \mathrm{I}$.

${ }^{65}$ Of course, Douglass does not actually say every American, but all "men." If there is an obvious complication to Douglass's thinking about DC, it is his near complete silence about women. Everyone can view themselves as free under the majestic dome of the American Capitol, so long as they are a man. In fact, Douglass's rhetoric of DC's improvement is almost always put in gendered terms; when he contemplates cosmopolitan opposition to the improvement of DC, he describes the urge to improve the city as "a natural and necessary outgrowth of a healthy manly and self respecting patriotism" ("National Capital” 448, my emphasis). This mode of speaking, however, is not unique to his DC writings - Douglass, despite his ardent support for the women's rights and women's suffrage, nevertheless used "manly" as a positive descriptor and "effeminate" as a pejorative one throughout his writings, when he was discussing the actions of men. For Douglass, women were humans who deserved all of the rights of humanity, but they remained a separate sex with different and appropriate characteristics, and the physical act of city-building was not their calling. As Waldo E. Martin Jr, The Mind of Frederick Douglass, i 40, puts it, "Woman's political equality, he argued, would change neither her familial roles and duties nor her exemplary nature." 
become a symbol of universal allegiance and belonging. The wealth and power that built DC are now the natural birthright of every American. The magnificence of the city represents what the labor of free and democratic people can do.

The concluding paragraph of the speech strikes a fervently unified note. Although the two preceding paragraphs do give a litany of DC's transgressions - "slavery, treason, and assassination" - Douglass lays out a vision of unity that includes even the South:

In its grandeur and significance, it may be a sign and a bond of the American Union, a pledge of righteousness that exalts a nation, a place where the best men and best women from all sections of our widely extended country shall delight to meet and bury their differences, renew their covenants of patriotism, and shake hands, not over a bloody chasm, but over a free, prosperous, happy, and progressive REPUBLIC. ${ }^{66}$

Thankfully, Douglass includes women in his description of this utopian space established in the capital. But the key fact here is that all sections - thus including the South - will be represented. Although it is difficult to reconcile this paean to universal belonging with Douglass's scathing critiques of the southern character, even they are invited to partake in the wonders of the capital, so long as they can leave behind the Civil War. Whereas L'Enfant emphasized the imperial nature of the US government, Douglass highlights its republican features. In this vision, not only will people from every region have a stake in the American undertaking, but people of every race and class also fully own the country's progress and prosperity, and are equally free to participate in it. ${ }^{67}$

Tragically, Douglass lived long enough to see that the future he foresaw in I 877 was not going to come about, at least not quickly. He saw the end of Radical Reconstruction, the unhelpful policies of Hayes, the election of Cleveland and the ascension of the Democratic Party, and the loss of social and political power so briefly gained by southern blacks. Douglass lived to see the reign of mob justice in the South and the myth of the black rapist of white women, the myth which he rightly diagnosed as a lie designed to make it easier for the South to

degrade the Negro by judicial decisions, by legislative enactments, by repealing all laws for the protection of the ballot, by drawing the colour line in all railroad cars and stations and in all other public places in the South, thus to pave the way to a final

${ }^{66}$ Douglass, “Our National Capital," 474.

${ }^{67}$ Again, Douglass's speech (originally written in 1875) and Ames's I 875 book are in accord. Ames, Ten Years in Washington, I 5 I: "The highest man in the nation owns nothing here [the Capitol] which does not belong equally to you. The Goddess of Liberty, gazing down from her shield, bestows no right upon the lofty which she does not extend equally to the lowliest of her sons." 
consummation which is nothing less than the Negro's entire disenfranchisement as an American citizen. ${ }^{68}$

Douglass did not live to see Jim Crow fully come to DC, but he could have predicted that Woodrow Wilson and his southern Democratic cabinet would resegregate the staffers working in the federal buildings, even as magnificent federal monuments to Lincoln and Grant were going up on the National Mall. The magnificence and unity of the city ultimately proved to be no bulwark against a return of the southern culture to DC.

\section{CODA: THE MCMILLAN COMMISSION AND THE UNITY OF DISUNION}

Although the racial inclusivity that Douglass called for was clearly not going to be realized in the early twentieth century, Douglass's dream of a more organized and grandiose DC was realized in those decades. The formal elements that his vision shared with L'Enfant's plan were as popular as ever, and the result was a L'Enfant revival. Most famously, in the last years of the nineteenth century, Senator James McMillan sought to transform the landscape of Washington, DC and reflect in that landscape the country's greatness. In keeping with the federal theme of unity out of disparate parts McMillan received a number of plans for transforming L'Enfant's Grand Avenue, and formed a commission to take all of those various ideas and create what John W. Reps calls "nothing less than a comprehensive development plan for all of central Washington." 69 If this goal sounds like the same one that animated L'Enfant, it is because L'Enfant's original plan was the official guiding light of the McMillan Commission. Although it has been correctly observed, particularly by Kirk Savage, that the McMillan Commission made many changes to L'Enfant's plan, they were clearly inspired by its spirit of a grand and unified capital. Missing, however, is the sense of cosmopolitan inclusion, particularly racial cosmopolitanism, that Douglass added. Savage argues that the commissioners left out the African American experience:

Their Mall was a white space, undisturbed by minority voices. All the grand talk of a "common people" with a "common destiny" papered over key absences ... The defeat of Reconstruction, the triumph of white supremacy, the daily struggles of African Americans to survive and prosper in a segregated world all found no place in the National Mall. $7^{\circ}$

${ }^{68}$ Frederick Douglass, "Why Is the Negro Lynched?" in The Life and Writings of Frederick Douglass, ed. Philip S. Foner, Volume IV (New York: International Publishers, 1955), 503.

${ }^{69}$ John W. Reps, Monumental Washington (Princeton: Princeton University Press, 1967), 91-92.

${ }^{70}$ Kirk Savage, Monument Wars (Berkeley: University of California Press, 2009), 17 I. 
Even the Great Emancipator is reimagined as the great unifier: "Together the two monuments reframed the Civil War as a story of national salvation, rather than liberation." ${ }^{11}$ In this respect, Savage is chillingly correct; slavery, the suffering of African Americans both before and after the war, and the damaging legacy of racism have been left out of the national narrative designed by the commissioners. To put it a different way, the McMillan Plan articulates the same spatial vision that Frederick Douglass so enthusiastically predicted a unified, coherent D.C. - but the social reconciliation that was supposed to accompany the geographical transformation has been lost. Douglass seems prophetic when he says, at the unveiling of the Freedmen's Memorial to Lincoln in I 876, "He [Lincoln] was ready and willing at any time during the first years of his administration to deny, postpone, and sacrifice the rights of humanity in the colored people to promote the welfare of the white people of this country." ${ }^{2}$ Lincoln had, according to Douglass, two great missions: "first, to save his country from dismemberment and ruin; and second, to free his country from the great crime of slavery." 73 In the McMillan Commission plan, the second mission has been almost completely erased. As Savage writes, the only reference to slavery in the original plan for the Lincoln Memorial is the vague and "abstract rhetoric of 'a new birth of freedom." 74 Just as the first founder of the country presided over a revolution which declared all men to be created equal while ignoring the plight of the slaves, the second founder is being remembered as a defender of the Union while the reason for that disunion - the plight of the slaves - is ignored. Whereas Douglass theorized a new, magnificent DC in which black labor would build a city for all human beings, the decades after his death saw the construction of a city that, magnificent though it was, once again elided the contributions of African Americans to the republic.

\footnotetext{
${ }^{71}$ Ibid., 170.

${ }^{72}$ Frederick Douglass, "Speech at the Freedmen's Monument," in The Life and Times of Frederick Douglass (New York: Gramercy Books, I 993), 477-90, 480-8 I.

${ }^{73}$ Ibid., 485 .

${ }^{74}$ Savage, 170.
} 